2019-07

\title{
Autoethnography and Activism: Movement, Intensity, and Potential
}

Gale, K::0000-0003-1296-9647

http://hdl.handle.net/10026.1/17558

$10.1177 / 1077800418800754$

Qualitative Inquiry

SAGE Publications

All content in PEARL is protected by copyright law. Author manuscripts are made available in accordance with publisher policies. Please cite only the published version using the details provided on the item record or document. In the absence of an open licence (e.g. Creative Commons), permissions for further reuse of content should be sought from the publisher or author. 


\title{
Autoethnography and Activism: Movement, Intensity, and Potential
}

Qualitative Inquiry

$1-3$

(C) The Author(s) 2018

Article reuse guidelines:

sagepub.com/journals-permissions DOI: I0.1 I77/10778004/8800754

journals.sagepub.com/home/qix

(S)SAGE

\section{Ken Gale' and Jonathan Wyatt ${ }^{2}$}

\begin{abstract}
In this short article, we pay attention to what an autoethnography might do. In relationality, we understand autoethnographic practices as assembling and dissembling bodies that are active in always territorializing space and in world making. They have the capacity to affect and be affected and, therefore, as performing and performative practices, they act and are acted upon. With Madison, we see these acts as activist, and we, therefore, see autoethnographic practice as always shifting, always about movement, intensity, and potentiality; it never resides, it lives in the creation of the next moment, the next step into the not yet known.
\end{abstract}

\section{Keywords}

acts of activism, affect, posthuman, activist autoethnography
As always in moments like this my movements in opening another writing space gives me a sense in which I am writing to and with you. In this materiality, the flesh and bloodness that is constitutive of this "to and with" continues in its intensive presencing, always generative of great potential, always in the knowing that something new, something useful, something worthwhile, and something deeply affective will be emergent. In this and with Barad, I am also deeply aware that this materiality, is fundamentally and, in always ever-changing ways, inevitably entangled with multiple discourses that are always there, animate in their intention to construct me, you, and us in particular ways.

Autoethnography still chooses to locate itself within the subject-centered proclivities of humanist thought and phenomenological inquiry and to subscribe to a metaphysics of being that seems to continue to resist the powerful presence and theorizing practices of affect theory, materiality, and the posthuman. Therefore, those who continue to wish to identify as "autoethnographers" must be encouraged to ask themselves a fundamental question. Is what I am doing worthwhile as a form of inquiry or am I simply indulging in the production of accounts that nurture forms of subjectification that serve to sustain researcher identities and practice representations that are fragile, unsustainable, and possibly even dishonest?

When we came to the Congress in 2010, before traveling south, we stayed for a few days in Chicago with Soyini Madison. It was the year her book Acts of Activism was published, so I also remember in the conversations we held with her at the time being deeply impressed by the notion of acts of activism (Madison, 2010). The arguments that she developed from her ethnographic field work in Ghana with local activists who were employing modes of performance as tactics of resistance and intervention in their day-to-day struggles for human rights were, and remain, very powerful. Her portrayal of the dynamic relationship between performance and activism, both in those conversations and subsequently when reading her book, had and continues to have a profound effect upon me and upon the research practices with which I engage.

I understood acts of activism, initially in my direct sensing of Soyini's spoken and written words, in terms of bodies performing themselves in forms of action that would bring about some kind of change. Obviously, in terms of the rhetoric of Soyini's project, this change would be for the good, it would be to enhance equality and to challenge injustice in the world. At the time, I was greatly assisted in forming this understanding through working with the simple, direct, and hugely animating performative question that Ron (Pelias) asks of a particular act: What work does it do?

This is an enormous and powerfully important question to ask of any body, of any body in action and of an act of activism: What work does it do?

\footnotetext{
'University of Plymouth, UK

${ }^{2}$ The University of Edinburgh, UK

Corresponding Author:

Ken Gale, Faculty of Arts and Humanities, Plymouth Institute of Education, University of Plymouth, Rolle Building, Plymouth, PL4 8AA, Devon, UK.

Email: kjgale@plymouth.ac.uk
} 
It is not enough to talk about the work that is done by bodies that are simply human. Posthuman thinking and theorizing teaches us that we have to think about bodies, all bodies, human, and nonhuman in relationality. It is not enough to talk only and in isolation about human bodies. With these concerns to do with autoethnography and activism, within a consideration of acts of activism, when asking such questions as: What can a body do? What work does a particular performance or act do? we are impelled to bring nonhuman as well as human bodies into these relationalities. Therefore, an activist autoethnography must come to terms with the rhetoric of Spinoza that says that all bodies, human and nonhuman, have the capacity to affect and be affected: Autoethnography, activism, and power cannot be understood outside of the micropolitics of this.

\section{Monday, April, 10: Acts of Autoethnographic Activism (Jonathan)}

Our Sundays since the turn of the year have found a new rhythm that day of the week has not had since the years way back before you and I met, before International Congress of Qualitative Inquiry, before autoethnography even, when I would go to church. We wake up not too early, dress in or take with us the requisite clothing and walk 10 min west into Stockbridge, a village within the city. We walk through its quiet high street and turn left and along to a nondescript two-storied 1970s concrete building out of keeping with its Georgian surroundings. We take the stairs toward the music and enter the circular room. On a good day, the sunlight enters through the skylights on the far side. A few are there already. Others arrive over the next 30 min, a gradual expansion as we, all of us, begin moving in and around each other on the wooden floor. This is what we now do on Sunday mornings and again on Wednesday evenings: we dance; an open, unfolding, slow-fast, intimate traveling of and between bodies. It has been an important discovery for me, this dancing. I feel I have found my feet, at last.

But, to get to the point, yesterday we gathered in a circle on the floor at the end, some $2 \mathrm{hr}$ after we began, and held hands. One of us spoke into the stillness, "This feels so important, this, our dancing, given what's happening in the world, given the madness." Another spoke of a march in support of the environment she was helping to organize, how there would be a gathering of dancers as part of it and who would like to join.

I had been sensing this too over recent months, how this act, this commitment, was becoming an act of resistance. I had heard about dance protests on the Golden Gate Bridge, at Standing Rock, and elsewhere. I could not articulate my own participation as activist, and I'm not sure yet whether I can. But I want to propose how that Sunday morning walk from home, past the waking market to that upstairs room of sound and sweat, gestures and shapes, speed and slowness, is an act of activism. It is a bringing of the multiple (human, nonhuman, more-than-human) bodies together onto a stage, into engagement; it is a move toward both vulnerability, as we become alert to our mutual intradependence, and strength — as we become alert to our mutual intra-dependence.

We call it dance but the word slips along with our skin as it touches others,' as feet, backs and hands encounter the warming floor pressing back on us. We call it dance. It is what it does that matters, the work it does, the work bodies do.

You may have spotted a clumsy, over-signaled analogy, but I think I am saying autoethnography is something like this dancing. Or can be. Inés Barcenas and I have just finished writing a chapter on supervising autoethnography, in which I write:

Supervising autoethnography happens amidst necessary doubt. I doubt autoethnography. I am troubled by it. I write against the assumptions it makes about the subject, about "experience," about inquiry (e.g., Wyatt \& Gale, 2013). I worry about this now, in an autoethnographic inquiry into supervising autoethnographic projects. I worry that in supervising autoethnography I am colluding with theoretical positions I challenge. How can I do this when I doubt? How can I supervise others and apparently disown the critiques I and others offer?

Yet. It is not about me. Supervising autoethnography is about others; and it is about the other in me. I may have doubts but autoethnography is precious and important and political. Autoethnography is a vanguard perhaps, a nod to what lies beyond, to what is possible. (Wyatt \& Taland, 2018)

Autoethnography is/remains the dance we make, the vital, ritual bringing of multiple bodies onto page/stage, intimate and vulnerable, angry and strong, necessary and problematic, "[posthuman] flesh to [posthuman] flesh scholarship" (Spry, 2001, p. 726).

\section{Activist Autoethnography as Dance, as Touch, as Reaching Out, as Moving Toward ... (Ken)}

What does autoethnography do? You talk about supervision practices and in this I am happy and energized by knowing that many of my students do autoethnography. All of these doings are different and what is important about all of them is just that; they are doing something different, they are doing things different from each other and more importantly different from what they would probably have done if they were my students, a mere 5 or 10 years ago. I sense that in these 
doings they are engaging in little acts of activism, whether they are aware of doing so or not. This is important and it is not enough. Now they need to be doing more. Now they need to make their autoethnographies less reflective, less personalized, less human/ centric and more relational, more non/human/centric and more engaged with the entanglements of materiality and discourse that enact the inevitability of lives.

In this and with them I also like to use the figure of the "dance" to help me with my sensing with and of relationality. To use dance as a means of describing the doings of autoethnography is a good thing because dance is about relationality, it is about the capacity to affect and be affected. Dancing involves touch and touch cannot live in the singular. In the dance, touch is multiple and complex; it is about movement, intensity, and potentiality; it never resides, it lives in the creation of the next moment; the next step into the not yet known. In the dance, touch is promiscuous; touching is gestural, political, affective and always more than the simply human. Touch is about actively creating new concepts, living in affect and about animating a politics of the event. In Manning's terms, it is about "worlding" and in reaching out to the world. An activist autoethnography has to live in and create these worldings and to engage movements that are all about what bodies do and can do.

\section{Declaration of Conflicting Interests}

The author(s) declared no potential conflicts of interest with respect to the research, authorship, and/or publication of this article.

\section{Funding}

The author(s) received no financial support for the research, authorship, and/or publication of this article.

\section{References}

Madison, D. S. (2010). Acts of activism: Human rights as radical performance. Cambridge, UK: Cambridge University Press.

Spry, T. (2001). Performing autoethnography: An embodied methodological praxis. Qualitative Inquiry, 7, 706-732.

Wyatt, J., \& Gale, K. (2013). Getting out of selves: An assemblage/ethnography? In T. Adams, S. Holman-Jones, \& C. Ellis (Eds.), Handbook of autoethnography (pp. 300-312). Walnut Creek, CA: Left Coast Press.

Wyatt, J., \& Taland, I. B. (2018). You never dance alone: Supervising autoethnography. In L. Turner, N. P. Short, A. Grant, \& T. E. Adams (Eds.), International perspectives on autoethnographic research and practice (pp. 218-227). London, England: Routledge.

\section{Author Biographies}

Ken Gale is a tutor, writer, and researcher working in the Faculty of Arts and Humanities at the University of Plymouth in the United Kingdom. He publishes widely, using writing and theorizing as practice in posthuman, new materialist and relationally creative fields of inquiry.

Jonathan Wyatt is a senior lecturer and Director of the Centre for Creative-Relational Inquiry at the University of Edinburgh. His article with Beatrice Allegranti, "Witnessing Loss: A Materialist Feminist Account," won the 2015 Norman K. Denzin Qualitative Research Award and his recent books include On (writing) families: Autoethnographies of presence and absence, love and loss, co-edited with Tony Adams and published by Sense. 